Journal of Thermal Engineering, Vol. 6, No. 5, pp. 724-735, October, 2020

Yildiz Technical University Press, Istanbul, Turkey

\title{
EXPERIMENTAL INVESTIGATION OF AN ALUMINIUM THERMOSYPHON AT NORMAL OPERATING CONDITIONS
}

\author{
Sachin V. Mutalikdesai ${ }^{1 *}$, Ajit M. Kate ${ }^{2}$
}

\begin{abstract}
The paper presents experimental investigation of an aluminium thermosyphon charged with acetone as working fluid. The effect of filling ratio on steady state performance of thermosyphon is experimentally investigated. Experimentation is performed at three different ratios namely $30 \%, 60 \%$ and $100 \%$. The effect of heat input and mass flow rate of water is also investigated. The heat input is varied between 50 to $300 \mathrm{~W}$ and mass flow rate is maintained in the range $30 \mathrm{lph}$ to $60 \mathrm{lph}$. A condenser section of thermosyphon is surrounded by two pass aluminium cooling block for effective condensation. The cooling block is design in such a way that water will absorbs maximum heat from working fluid in condenser section. The temperature at outer surface of thermosyphon is recorded with the help of temperature sensors. The temperature distribution at outer surface of evaporator and condenser observed to be almost uniform for all mass flow rates and filling ratios. The heat transfer limitations are not encountered for any of thermosyphon. The filling ratio has significant effect on outer surface temperature of evaporator. The surface temperature of evaporator increases by $20 \%$ with increasing the filling ratio at $150 \mathrm{~W}$ heat input and $30 \mathrm{lph}$ mass flow rate. The results also indicate that mass flow of cooling water has significant effect on total thermal resistance of thermosyphon at lower input. For $50 \mathrm{~W}$ heat input, minimum thermal resistance is recorded as $0.269{ }^{\circ} \mathrm{C} / \mathrm{W}$ at $60 \%$ filling ratio and $50 \mathrm{lph}$ mass flow rate. While for a same heat input, maximum thermal resistance is recorded as $1.077^{\circ} \mathrm{C} / \mathrm{W}$ at $100 \%$ filling ratio and 60 lph mass flow rate.
\end{abstract}

Keywords: Thermosyphon, Filling Ratio, Mass Flow Rate, Surface Temperature, Total Thermal Resistance

\section{INTRODUCTION}

The budding energy demand of modern world leads to develop efficient energy utilization device. Different techniques in combination with natural and forced convection are used for proper utilization of available heat energy. During working on refrigeration problem Gaugler in 1944 first introduced heat pipe [1]. The heat pipe or thermosyphon is evacuated sealed tube filled with appropriate quantity of working fluid. It transfers the heat even at lower temperature difference between source and sink. The condensate return mechanism differentiates heat pipe from thermosyphon. In thermosyphon condensate returns to evaporator solely due to gravity, while in heat pipe it returns through wick structure. The evaporation and condensation of working fluid transport the heat from source to sink. In last few decades, extensive research has been preformed to investigate effect of various parameters on thermal operation of thermosyphon.

Yong et al. [2] examined performance of grooved surface thermosyphon with various fill charge ratio. The copper thermosyphon containing FC-12 (C6F14) as working fluid was used during study. The improvement in heat transfer coefficient was observed at condenser of grooved thermosyphon by increasing fill charge ratio. For evaporator, negligible change in heat transfer coefficient was found. Ong and Alahi [3] investigated performance copper thermosyphon charged with R-134a refrigerant. The increase in heat transfer flux was observed by increasing fill ratio, bath and condenser temperature difference and coolant flow rate. Noie [4] examined performance of copper thermosyphon charged with distilled water. For each aspect ratio maximum heat transfer rate was observed at different filling ratio. Hussein et al. [5] experimentally investigated flat plate solar collector with different cross section geometries of wickless heat pipe. Circular, semi- circular and elliptical sections were used during investigation. The elliptical solar flat plate collector shows better performance as compared to circular at lower fill

This paper was recommended for publication in revised form by Regional Editor Tolga Taner

${ }^{1}$ Trinity College of Engineering and Research, Pune, Maharashtra, India, sachin.3182@gmail.com

${ }^{2}$ Zeal College of Engineering and Research, Pune, Maharashtra, India, kateajit22@gmail.com

${ }^{\star} E$-mail address: sachin.3182@gmail.com

Orcid id: 0000-0002-7355-7163, 0000-0002-3594-9019

Manuscript Received 11 October 2018, Accepted 18 December 2018 
ratio. Guo and Nutter [6] studied axial conduction through copper thermosyphon. Two R134a filled thermosyphon were tested. The one of them had thermal break inside adiabatic section, to resist axial conduction. The axial conduction increases evaporation, condensation and overall heat transfer coefficient of thermosyphon. Jouhara and Robinson [7] experimentally investigated performance of small diameter copper thermosyphons charged with water and dielectric liquids (FC-84, FC-77 and FC-3283). The thermal resistance and heat transfer capability of water charged thermosyphon was better compared with dielectric liquids. Kannan and Natarajan [8] examined performance of thermosyphon for waste heat recovery system. The effect of working fluid, filling ratio was examined at varying heat input. The dryout limitation was occurred for a filling ratio less than $20 \%$, while flooding limitation was observed for large filling ratio. For operating temperature more than $40{ }^{\circ} \mathrm{C}$, water charge thermosyphon perform better compared with ethanol, methanol and acetone charged thermosyphon.

Parametthanuwat et al. [9] developed correlation to predict heat transfer rates of silver naofluid filled copper thermosyphon. The dimensionless parameters were used to develop correlation. The standard deviation of $5 \%$ between predicated and experimental heat flux confirm the applicability of correlation. Amatachaya and Srimuang [10] compared heat transfer characteristics of flat and circular copper thermosyphon charged with distilled water. The flat thermosyphon indicates higher wall temperature compared to circular thermosyphon. It was also found that thermal performance of flat thermosyphon was superior to circular thermosyphon. Alizadehdakhel et al. [11] developed CFD model to predict the temperature profile in copper thermosyphon. Experimentation was also carried to investigate the effect of input heat flow and fill ratio. The experimental result indicates that there is an optimum value of the fill ratio for each value of input energy to the evaporation section. A good agreement between CFD model and experimental results was obtained in terms of temperature profile. Kate and Kulkarni [12] experimentally investigated performance of stainless steel elliptical wickless heat pipe charged with water and ethanol. The wall temperature of ethanol charged wickless heat pipe was observed higher than water. Ong and Tong [13] examined that performance of stainless steel thermosyphon was independent of fill ratio and inclination within the limits of the experimental investigation. Thanaphol Sukchana and Chaiyun Jaiboonma [14] investigated the effect of filling ratio and adiabatic length on thermal efficiency of R-134a charged straight long copper heat pipe. The result indicates that the filling ratio have more significant effect on the thermal efficiency than adiabatic length. Solomon et al. [15] investigated effect of anodized surface on performance of aluminium thermosyphon. An acetone was used as working fluid with $100 \%$ filling ratio. The effect of anodized surface was noteworthy at evaporator and negligible at condenser in terms of thermal resistance and heat transfer coefficient. Hamidreza et al. [16] developed a twodimensional numerical model to simulate the transient operation of copper thermosyphon with various working fluid filling ratios. Simulation result indicates that for under filled thermosyphon temperature of evaporator rises due to dryout. It also indicates that thermal resistance was lower for optimally-filled thermosyphon and higher for overfilled thermosyphon. Engin Gedik [17] examined thermal performance of water, ethylene glycol and ethanol charged thermosyphon at different flow rate of cooling water. The effect of inclination angle and heat input on thermal performance was also studied. It was observed that for each working fluid thermal performance was best at different flow rate and heat input. Jafari et al. [18] experimentally investigated evaporation and condensation heat transfer of water charged copper thermosyphon. The experimental results were compared with existing correlations indicates deviation of $\pm 30 \%$. Hence the set of appropriate correlations were developed for accuracy within $\pm 10 \%$. Lataoui and Jemni [19] investigated performance of stainless steel thermosyphon filled with water, ethanol and acetone. The dryout limit occurs at evaporator for underfilled thermosyphon. The experimental heat transfer coefficient at evaporator was compared with existing pool boiling correction and good agreement was found for ethanol filled thermosyphon. For water and acetone filled thermosyphon reasonable agreement was found in experimental and predicated heat transfer coefficient. Naresh and Balaji [20] experimentally investigated heat transfer from internally finned thermosyphon. The six fins that are integral part of copper thermosyphon were provided at condenser section. The thermosyphon was filled with water and acetone as working fluid. The fins provided at condenser section improve thermal performance of thermosyphon due to addition condensation. The $17 \%$ temperature reduction was found between source and sink, where as $35.48 \%$ reduction in thermal resistance was found at lower heat input. Ozdemir and Sozbir [21] reviewed single and two-phase pressure drop characteristics and flow boiling instabilities 
in micro-channels. The two phase pressure drop characteristics in micro-scale matches with conventional-scale channels. Flow boiling instabilities has significant affect on performance of system and may cause system failures.

The literature indicates that extensive work has been carried out for investigating the performance of thermosyphon with copper pipe material. It also indicates that optimum filling ratio depends on number of parameters such as working fluid, container (pipe) material, aspect ratio, geometry, heat input, rate on condensation and operating conditions. Hence, change in these parameters modifies the filling ratio from one thermosyphon to another. A detailed experimental investigation is necessary to predict the performance of thermosyphon for certain application. The present investigation aims for medium size electronic cooling application. In electronic application weight of system is primary important with functional approach. Hence light weight aluminium thermosyphon are designed and tested for certain operating parameters. The effect of filling ratio, heat input and coolant mass flow rate on steady state performance of thermosyphon has been experimentally investigated.

\section{EXPERIMENTAL SETUP AND PROCEDURE}

An experimental test rig has been designed and fabricated to investigate the performance of thermosyphon. Figure 1 (a) and (b) indicates line diagram and actual experimental test rig respectively. The plain aluminium thermosyphon of length $350 \mathrm{~mm}$, outer diameter $19.05 \mathrm{~mm}$, thickness $1 \mathrm{~mm}$ and charged with acetone as working fluid is used during experimentation. The thermosyphon consists of an evaporator, adiabatic and condenser section of length $100 \mathrm{~mm}, 100 \mathrm{~mm}$ and $150 \mathrm{~mm}$ respectively. During the testing heat input is varied between 50 and $300 \mathrm{~W}$. The dimensions of thermosyphon are determined from heat transfer limitations at maximum heat input of $300 \mathrm{~W}$.

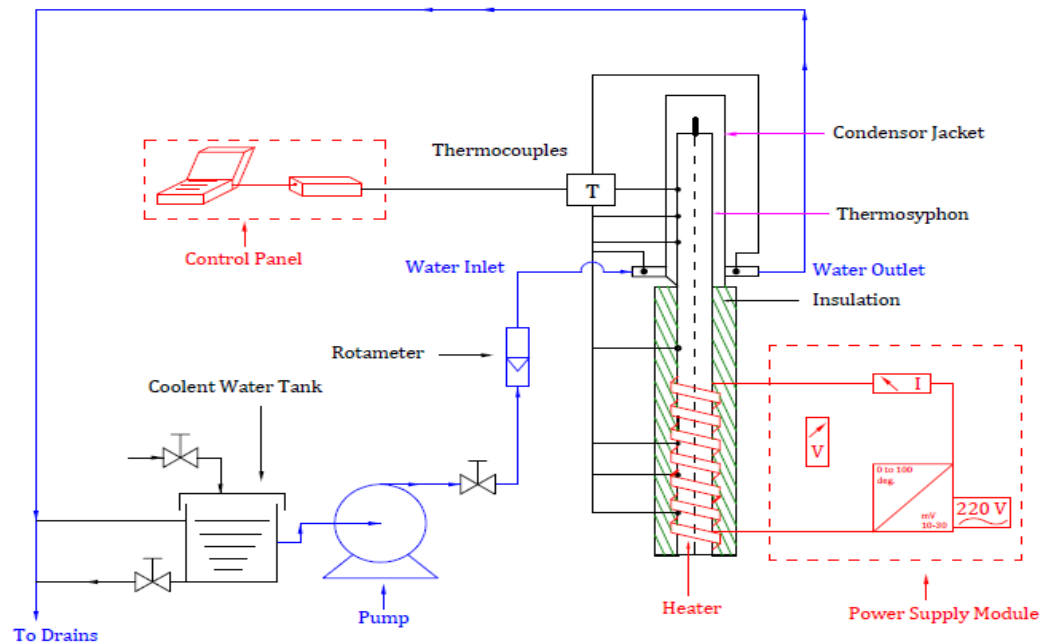

(a) Line diagram

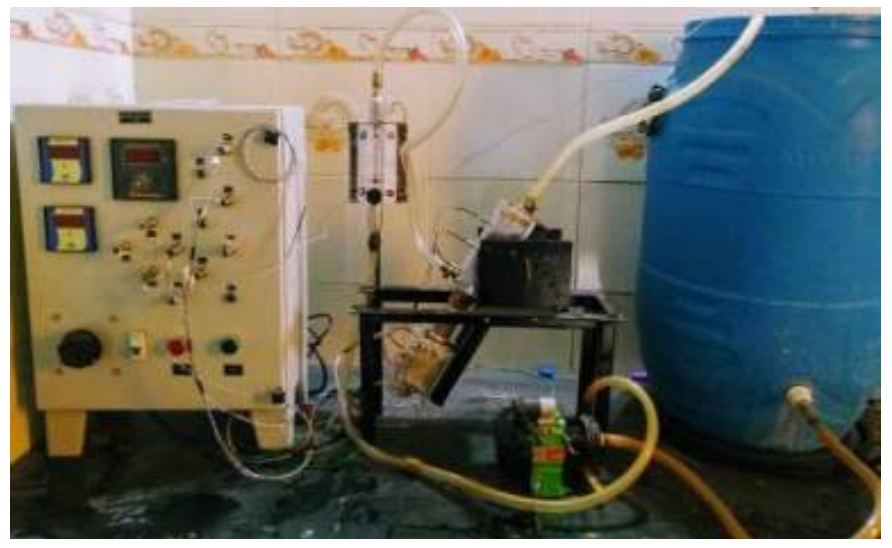

(b) Actual set up

Figure 1. Experimental test rig for thermosyphon testing 
The two pass aluminium cooling block is designed at condenser section. A mass flow rate of cooling water is varied between 30 to $60 \mathrm{lph}$. It is measured by using rotameter. For temperature measurement at various locations ten Pt 100 type RTD are used. The location of temperature sensors along the length of thermosyphon is as shown in Figure 2. Seven temperature sensors are attached at outer surface of thermosyphon. Evaporator and condenser section is attached with three temperature sensors each. The temperature sensor attached at centre of adiabatic section represents vapour temperature of working fluid. The water temperature at inlet and outlet of cooling block is measured by two separate Pt 100 type temperature sensors attached at respectively location. The temperature of ambient air was also recorded.

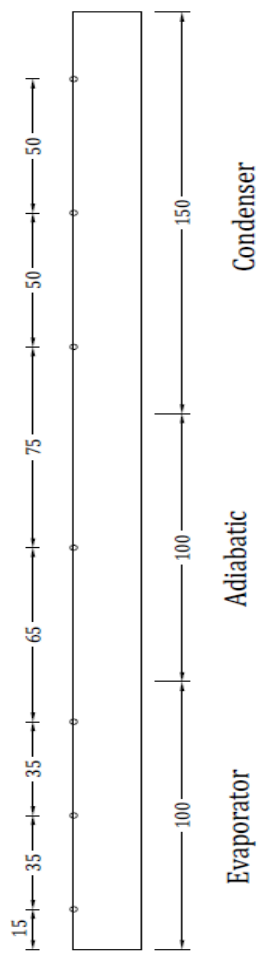

Figure 2. Location of temperature sensors along length of thermosyphon

The capability of thermosyphon to transfer fast heat from its internal structure may damage thermosyphon if heat is not dissipated at condenser section. Hence cooling water is supplied to condenser section before the heat supply at evaporator section. The mass flow rate of coolant water is controlled by hand operated ball valve. The heat is supplied to evaporator section, after stabilizing mass flow rate of water. Steady state temperature readings are recorded. Steady state has been considered when the temperature variation is not more than $0.1{ }^{\circ} \mathrm{C}$ for a span of 15 min. The same practice is maintained to record the readings at various heat inputs. The summary of experimental parameters is as shown in Table 1.

Table 1. Experimental parameters

\begin{tabular}{|l|l|}
\hline \multicolumn{1}{|c|}{ Parameters } & \multicolumn{1}{c|}{ Specification / Range } \\
\hline Thermosyphon Material & Aluminium \\
\hline Working Fluid & Acetone \\
\hline Heat Input & 50 to $300 \mathrm{~W}$ (Step size of $50 \mathrm{~W})$ \\
\hline Filling Ratio & $30 \%, 60 \%$ and $100 \%$ \\
\hline Cooling Water Mass Flow Rate & 30 to $60 \mathrm{lph}($ Step size of $10 \mathrm{lph})$ \\
\hline
\end{tabular}


The uncertainty in measuring parameters such as voltage, current, temperature and mass flow rate of water is assumed to be least count of the corresponding measuring devices. The uncertainty for voltage, current, temperature and mass flow rate is $1 \mathrm{~V}, 0.01 \mathrm{~A}, 0.1{ }^{\circ} \mathrm{C}$ and $\pm 2 \mathrm{lph}$ respectively. The uncertainty for heat input is calculated as $0.84 \%$, at maximum input of $300 \mathrm{~W}$.

The total thermal resistance is calculated for evaluating the thermal performance of thermosyphon. Neglecting heat losses to the surrounding, heat supplied at evaporator section is calculated as,

$$
Q_{\text {in }}=(V)(I)
$$

The heat rejected by thermosyphon at condenser section is determine as,

$$
Q_{\text {out }}=\dot{m}_{w} c_{p w}\left(T_{\text {out }}-T_{\text {in }}\right)
$$

The thermal resistance at evaporator and condenser section is determine by

$$
\begin{aligned}
& R_{e}=\frac{\Delta T_{e}}{Q_{\text {in }}} \\
& R_{c}=\frac{\Delta T_{c}}{Q_{\text {out }}} \\
& R_{t}=\frac{\Delta T}{Q_{\text {out }}}
\end{aligned}
$$

where $\Delta \mathrm{T}=\overline{\mathrm{T}}_{\mathrm{e}}-\overline{\mathrm{T}}_{\mathrm{c}}, \Delta \mathrm{T}_{\mathrm{e}}=\overline{\mathrm{T}}_{\mathrm{e}}-\mathrm{T}_{\mathrm{v}}$ and $\Delta \mathrm{T}_{\mathrm{c}}=\mathrm{T}_{\mathrm{v}}-\overline{\mathrm{T}}_{\mathrm{c}}$

\section{RESULTS AND DISCUSSION}

The effect of water mass flow rate and filling ratio on the thermal performance of aluminium thermosyphon is experimentally investigated at steady state condition. From literature it was found that to avoid the dry out limitation in thermosyphon filling ratio must be greater than $20 \%$. During experimentation minimum filling ratio is maintained as $30 \%$ and maximum filling ratio is $100 \%$ (equivalent to volume of evaporator). The thermosyphon is charged with $7 \mathrm{ml}, 14 \mathrm{ml}$ and $23 \mathrm{ml}$ of acetone for a filling ratio of $30 \%, 60 \%$ and $100 \%$ respectively. The experiments are performed at different heat inputs. An acetone compatible with selected thermosyphon material is used as working fluid. [1] Table 2 indicates various properties of acetone at boiling temperature.

Table 2. Thermo-physical properties of acetone at boiling temperature [1] Acetone $\left(\mathrm{CH}_{3}\right)_{2} \mathrm{CO}$ : Molecular Mass $58.1\left(\mathrm{~T}_{\text {sat }}=56.25{ }^{\circ} \mathrm{C} ; \mathrm{T}_{\mathrm{m}}=-93.15^{\circ} \mathrm{C}\right)$

\begin{tabular}{|l|l|l|}
\hline \multicolumn{1}{|c|}{ Properties } & \multicolumn{1}{c|}{ Value } & \multicolumn{1}{c|}{ Unit } \\
\hline Boiling point & 56.2 & ${ }^{\circ} \mathrm{C}$ \\
\hline Saturated pressure & $1.046 \times 10^{5}$ & $\mathrm{~Pa}$ \\
\hline Latent heat & $520.56 \times 10^{3}$ & $\mathrm{~J} / \mathrm{kg}$ \\
\hline Density of liquid & 748.5 & $\mathrm{~kg} / \mathrm{m}^{3}$ \\
\hline Density of vapour & 2.123 & $\mathrm{~kg} / \mathrm{m}^{3}$ \\
\hline Thermal conductivity of liquid & 0.169 & $\mathrm{~W} / \mathrm{m}-\mathrm{K}$ \\
\hline Thermal conductivity of vapour & 0.0139 & $\mathrm{~W} / \mathrm{m}-\mathrm{K}$ \\
\hline Surface tension & $19.09 \times 10^{-3}$ & $\mathrm{~N} / \mathrm{m}$ \\
\hline Specific heat of liquid & $2.28 \times 10^{3}$ & $\mathrm{~J} / \mathrm{kg}-\mathrm{K}$ \\
\hline Specific heat of vapour & $2.123 \times 10^{3}$ & $\mathrm{~J} / \mathrm{kg}-\mathrm{K}$ \\
\hline
\end{tabular}




\section{Temperature at Outer Surface along the Length of Thermosyphon}

The outer surface temperature distribution along the length of thermosyphon for $30 \%$ filling ratio at different heat inputs and water mass flow rates is as shown in Figure 3 (a-d). The heat supplied to evaporator section boils liquid pool of acetone, results in increase of evaporator temperature. The liquid starts converting into vapour as soon as it attains saturation temperature. Due to buoyancy the vapour travels to condenser and reject its latent heat to the cooling water circulated around condenser section. Hence vapour gets condensate and falls back to evaporator in the form of condensate film along inner surface of thermosyphon, which cools the evaporator. Due to evaporation and condensation of working fluid the negative temperature distribution gradient has obtained between evaporator and condenser section of thermosyphon. As expected, outer surface temperature along the length of thermosyphon decreases.

The temperature at outer surface of thermosyphon gradually increases with increase in heat input. The heat input is directly proportion to temperature; hence increase in heat input results in temperature rise at all positions of outer surface. The almost uniform temperature distribution is also observed along outer surface of evaporator and condenser section. The phase change process in evaporator and condenser section results in uniform temperature at respective section. The similar trend is observed for all the mass flow rate of water with slight variation in outer surface temperature.

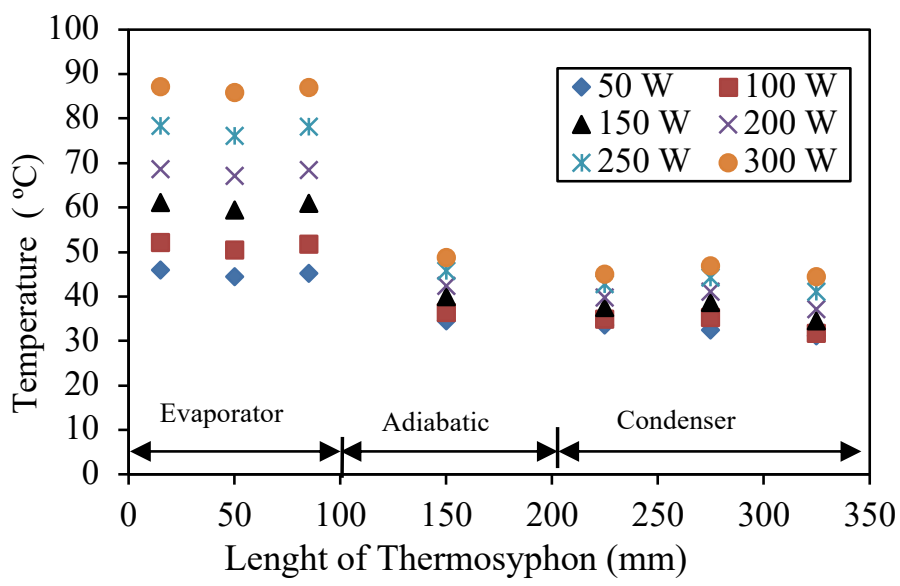

(a)

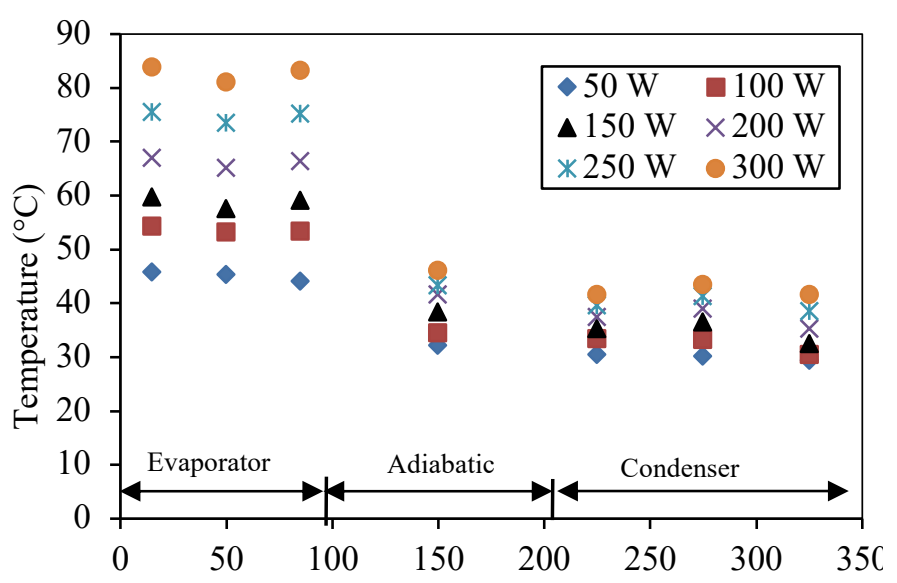

Length of Thermosyphon (mm)

(c)

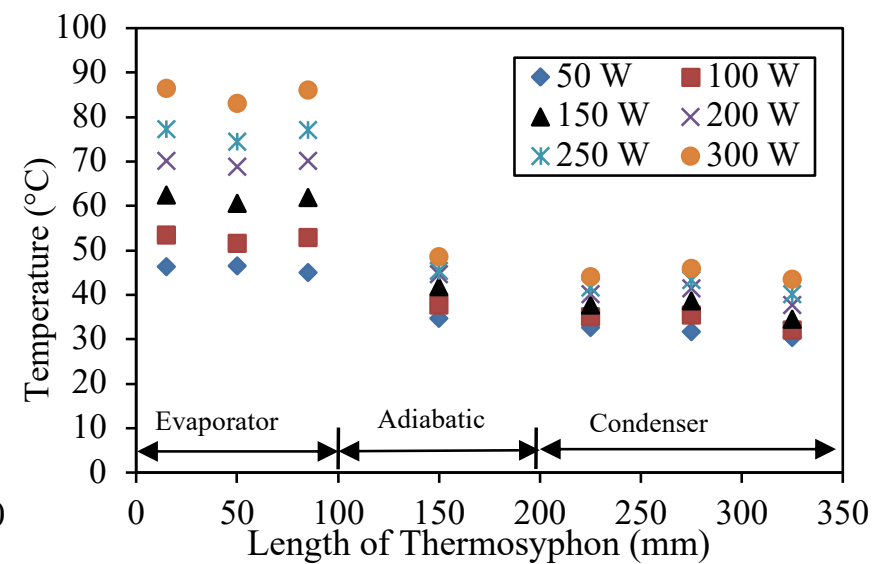

(b)

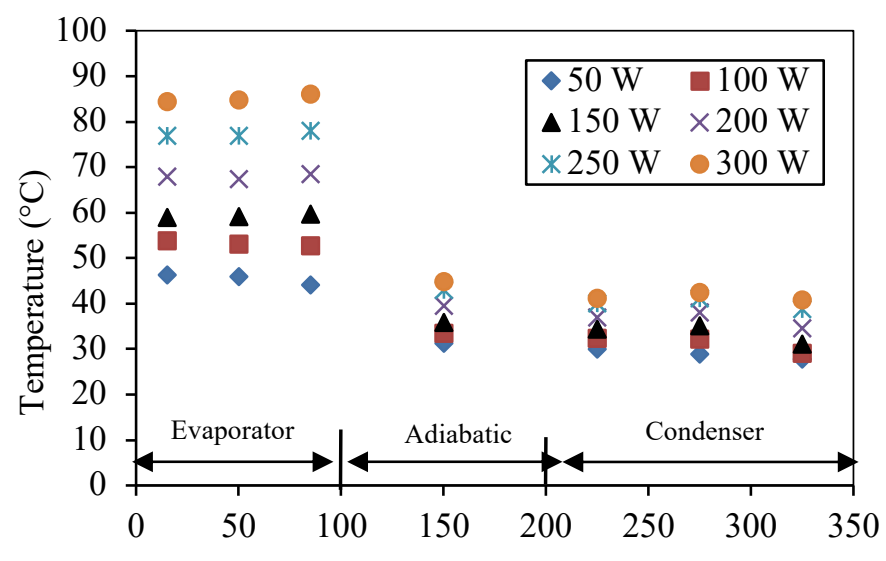

Length of Thermosyphon

(d)

Figure 3. Outer surface temperature along length of thermosyphon for $F R=30 \%$

(a) $30 \mathrm{LPH}$ (b) $40 \mathrm{LPH}$ (c) $50 \mathrm{LPH}$ (d) $60 \mathrm{LPH}$ 
Figure 4 (a-d) indicates outer surface temperature distribution along the length of thermosyphon for $60 \%$ filling ratio at different heat inputs and water mass flow rates. The smaller temperature gradient is obtained at outer surface of evaporator for low heat input of $50 \mathrm{~W}$. The increase in heat input also increases temperature gradient at outer surface of evaporator. The maximum temperature is observed at the top of evaporator outer surface. The improved condensation drives the liquid to the bottom pool of evaporator, results in temperature drop at bottom surface. The similar trend is observed for all the mass flow rate of water at condenser. For $30 \%$ and $60 \%$ filling ratio, $0.4{ }^{\circ} \mathrm{C}$ and $2{ }^{\circ} \mathrm{C}$ temperature gradient is obtained respectively for a heat input of $300 \mathrm{~W}$ at $30 \mathrm{lph}$ mass flow rate.

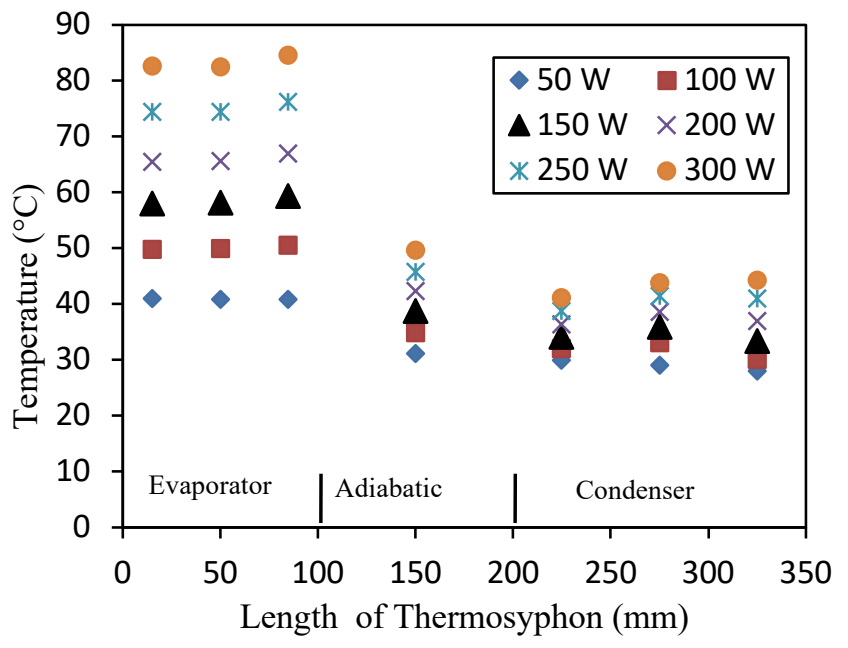

(a)

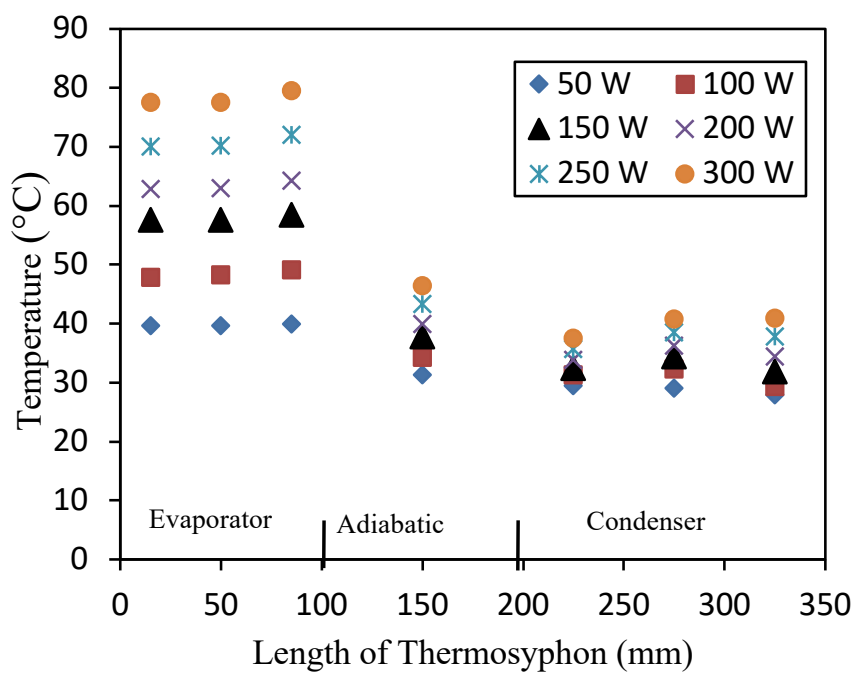

(c)

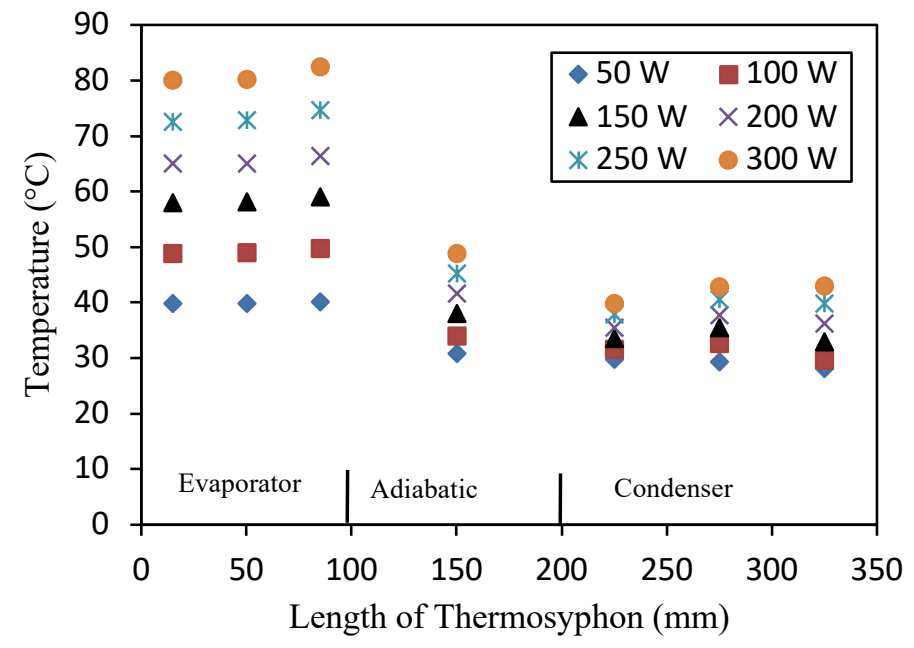

(b)

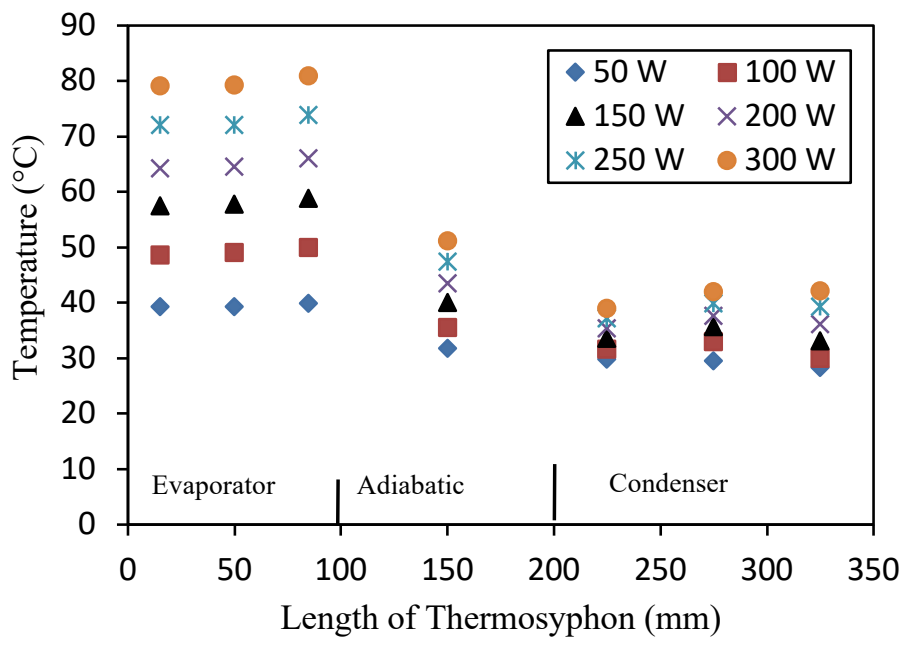

(d)

Figure 4. Outer surface temperature along length of thermosyphon for $F R=60 \%$

(a) $30 \mathrm{LPH}$ (b) $40 \mathrm{LPH}$ (c) $50 \mathrm{LPH}$ (d) $60 \mathrm{LPH}$

The variation of outer surface temperature along the length of thermosyphon for $100 \%$ filling ratio at different heat inputs and water mass flow rates is as shown in Figure 5 (a-d). The bottom two temperature sensors at outer surface of evaporator indicate nearly same temperature as compared to third. The more liquid inventory results 
in higher temperature gradient at evaporator section. For $300 \mathrm{~W}$ input, the temperature gradient at outer surface of evaporator is recorded as $4{ }^{\circ} \mathrm{C}$ at $30 \mathrm{lph}$ mass flow rate. It indicates that increase in liquid fill quantity also increases the temperature gradient in evaporator.

For $100 \%$ filling ratio, higher outer surface temperature along the length of thermosyphon is observed as compared to $30 \%$ and $60 \%$ filling ratio. The overfilling of working fluid degrades condensation and results in higher surface temperature. The average surface temperature difference between evaporator and condenser section also increases due to increase outer surface temperature of thermosyphon. For $100 \%$ filling ratio effectively designed condenser block results in lower surface temperature of thermosyphon as compared to Solomon et al. [15]. The similar temperature profile was reported by Naresh and Balaji [20] for cooper thermosyphon with acetone as working fluid for $20 \%, 50 \%$ and $80 \%$ filling ratio respectively.

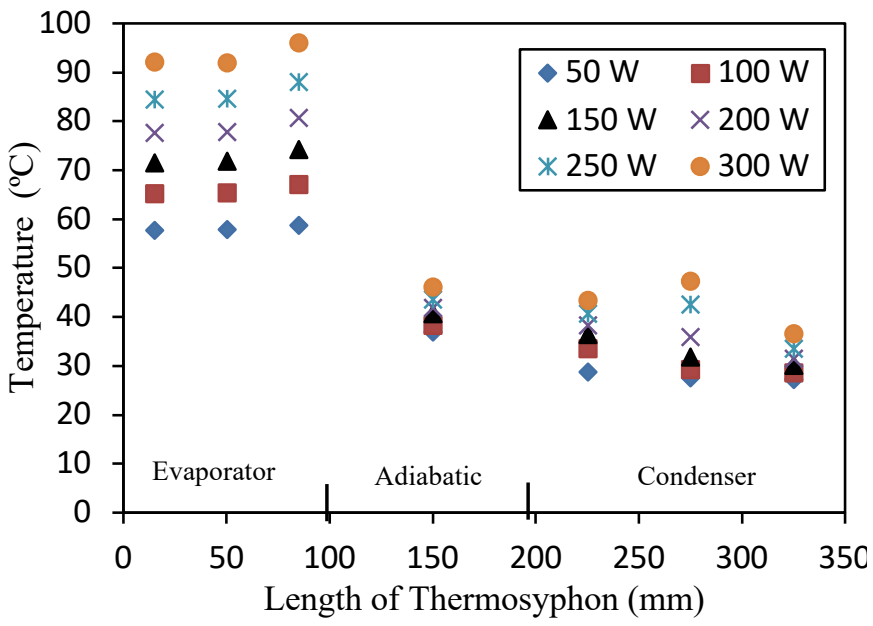

(a)

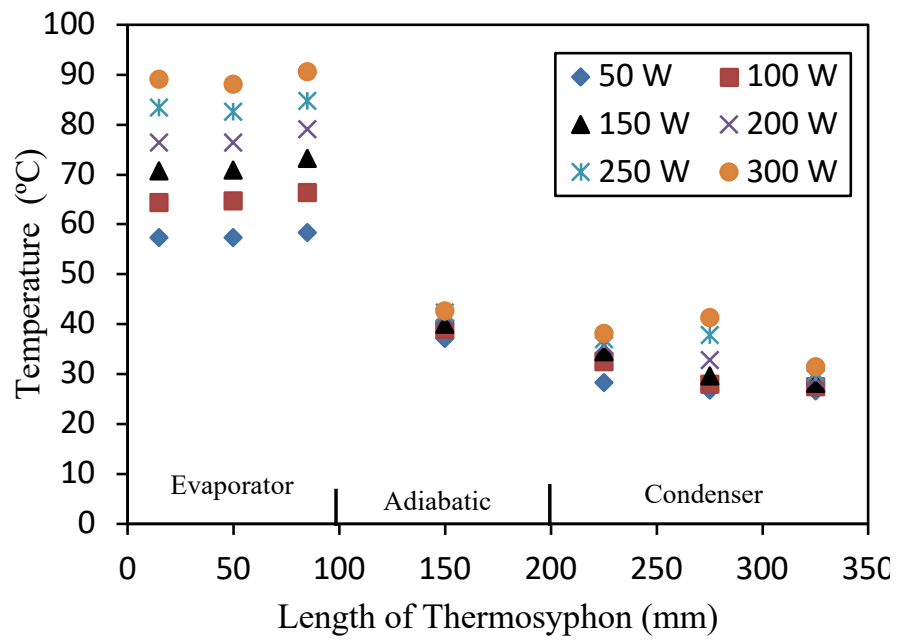

(c)

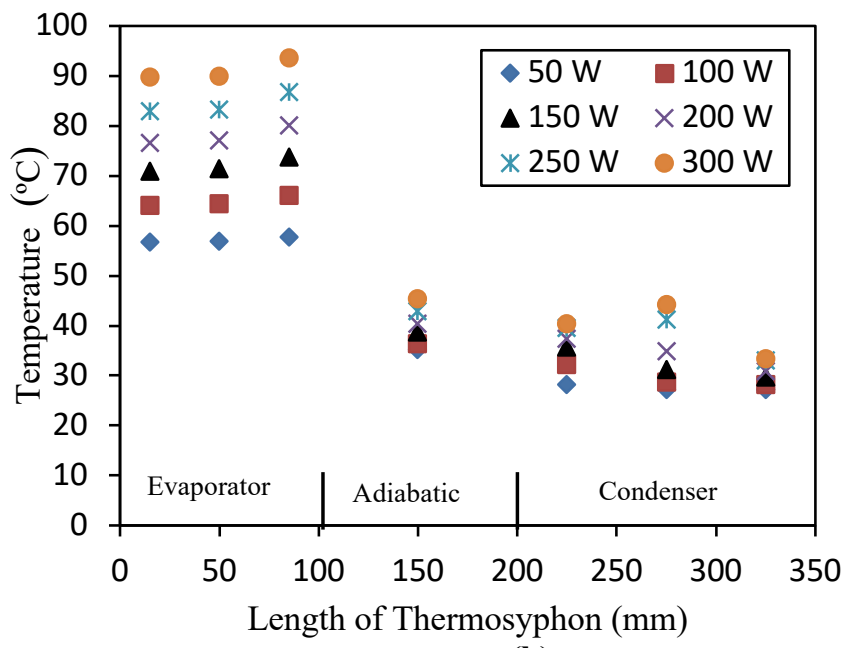

(b)

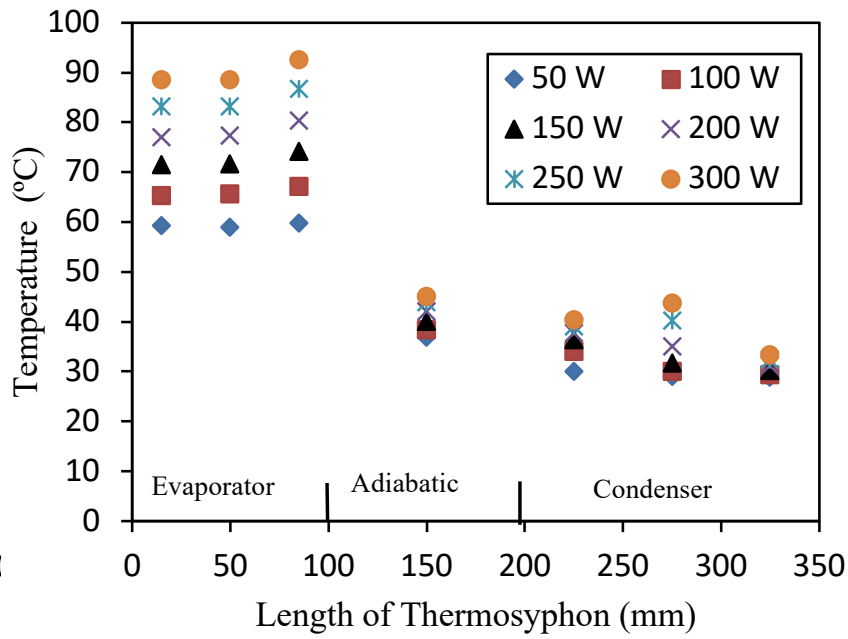

(d)

Figure 5. Outer surface temperature along length of thermosyphon for $\mathrm{FR}=100 \%$

(a) $30 \mathrm{LPH}$ (b) $40 \mathrm{LPH}$ (c) $50 \mathrm{LPH}$ (d) $60 \mathrm{LPH}$ 


\section{Total Thermal Resistance for Different Filling Ratio with Various Mass Flow Rate}

Figure 6 (a-c) shows the total thermal resistance of thermosyphon for a filling ratio of $30 \%, 60 \%$ and 100 $\%$ at different mass flow rates. It is observed that total thermal resistance decreases with increase in heat input for entire range of mass flow rates. The variation in total thermal resistance for different mass flow rate is significant at lower heat input upto $100 \mathrm{~W}$. The quantity of liquid pool and flow distribution results in variation of total thermal resistance in thermosyphon. The heat supplied to evaporator section converts liquid into vapour. A vapour travel to condenser section and rejects the heat to cooling medium. It results in condensation by the time the condensate returns to evaporator, the surface temperature of evaporator increases due to famished of liquid. The condensation and evaporation processes are less effective at low heat input results in higher total thermal resistance. The increase in heat input also increases rate of evaporation and condensation cycle, results in quick return of condensate. Hence, low total thermal resistance is observed at high heat inputs.

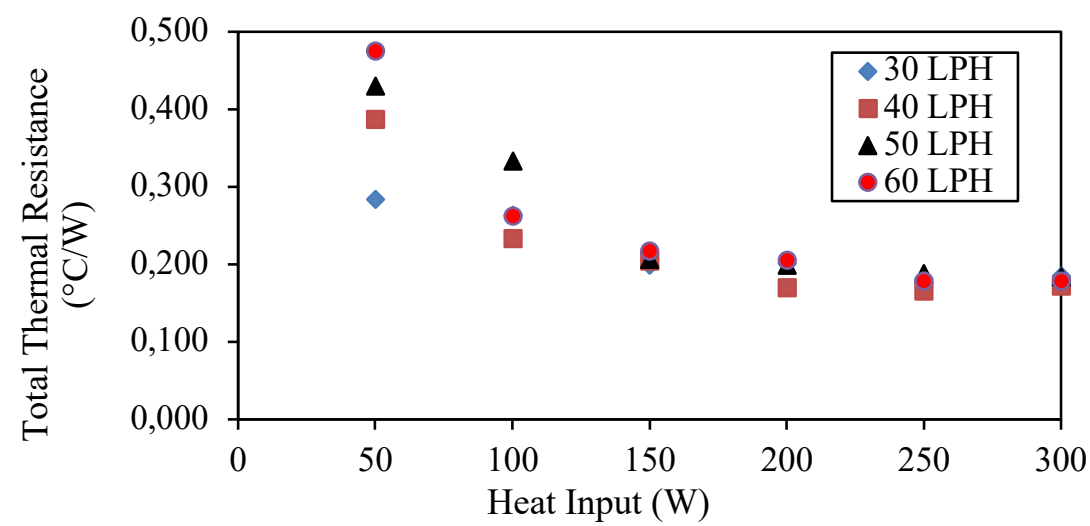

(a)

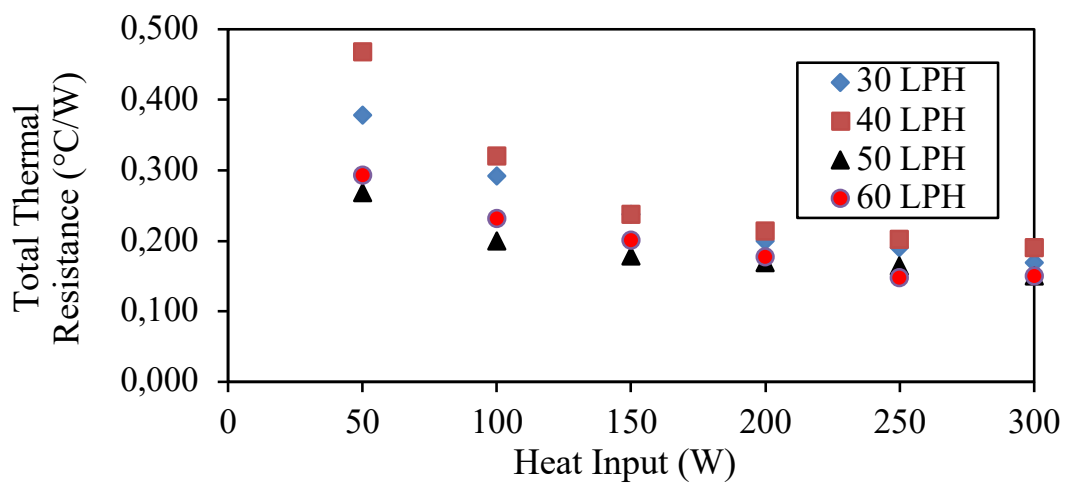

(b)

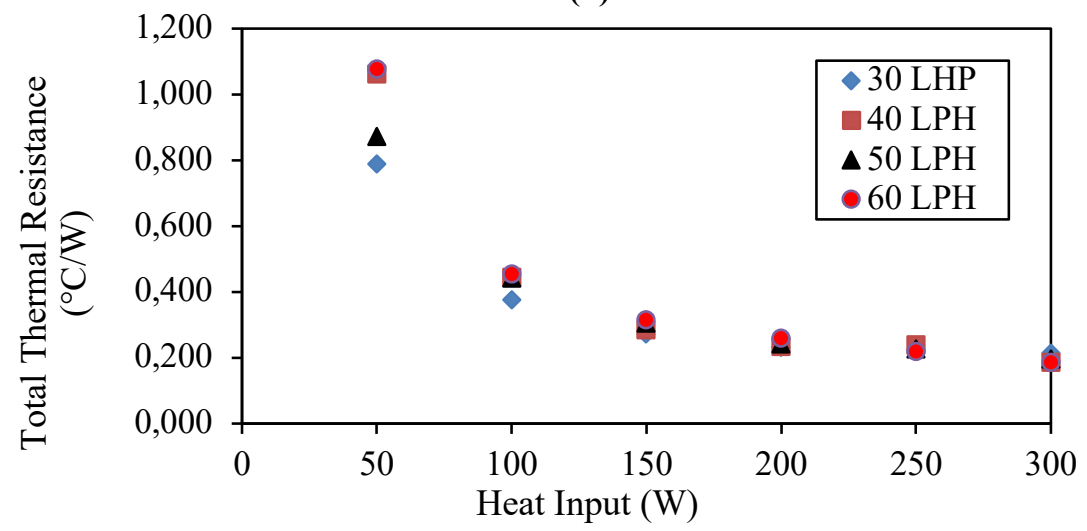

(c)

Figure 6. Total thermal resistance of thermosyphon for different mass flow rate of water

(a) $\mathrm{FR}=30 \%$ (b) $\mathrm{FR}=60 \%$ (c) $\mathrm{FR}=100 \%$ 
The minimum total thermal resistance for each filling ratio is obtained for different mass flow rates. For $30 \%$ and $100 \%$ filling ratio, total thermal resistance is minimum at 30 lph mass flow rate. The valve of minimum total thermal resistance is 0.283 and $0.789^{\circ} \mathrm{C} / \mathrm{W}$ respectively at a low heat input of $50 \mathrm{~W}$. While for $60 \%$ filling ratio, total thermal resistance is minimum at $50 \mathrm{lph}$ mass flow rate. The valve of minimum total thermal resistance is $0.269^{\circ} \mathrm{C} / \mathrm{W}$ at a low heat input of $50 \mathrm{~W}$. For $100 \%$ filling ratio, the total thermal resistance at 40 and $60 \mathrm{lph}$ mass flow rate are similar to Solomon et al. [15].

Table 3. Comparison of experimental results with Solomon et al. for FR=100 \% [15]

\begin{tabular}{|c|c|c|}
\hline $\begin{array}{c}\text { Heat } \\
\text { Input }\end{array}$ & \multicolumn{2}{|c|}{ Thermal Resistance $\left({ }^{\circ} \mathrm{C} / \mathrm{W}\right)$} \\
\hline & Present Work (60 lph) & Solomon et al. [15] (Approximate) \\
\hline $50 \mathrm{~W}$ & 1.077 & 1.020 \\
\hline $250 \mathrm{~W}$ & 0.218 & 0.410 \\
\hline
\end{tabular}

\section{CONCLUSION}

The thermal performance of aluminium thermosyphon is experimentally investigated. The effect of filling ratio and coolant mass flow rate on thermal performance of thermosyphon is investigated. An experimentation is performed at varies heat input and following conclusions are drawn

- The temperature distribution is almost uniform in evaporator and condensation section. The phase change process of working fluid results in uniform temperature distribution.

- The temperature at outer surface of thermosyphon increases with increase in heat input. The maximum temperature in thermosyphon is recorded at $300 \mathrm{~W}$ heat input.

- The mass flow of cooling water has significant impact on total thermal resistance at lower input.

- The thermal resistance decreases with increase in heat input. For $30 \%$ and $100 \%$ filling ratio, thermal resistance is minimum at $30 \mathrm{lph}$. While for $60 \%$ filling ratio, thermal resistance is minimum at $50 \mathrm{lph}$.

- The filling ratio has significant impact on outer surface temperature of evaporator. The increase in filling ratio also increases temperature of evaporator section. For $30 \mathrm{lph}$ mass flow rate average outer surface temperature of evaporator increases by $20 \%$ at $150 \mathrm{~W}$ heat input.

\section{NOMENCLATURE}

$F R \quad$ Filling ratio (ratio of volume of working fluid to volume of evaporator section)

$V \quad$ Voltage, volts

I Current, amp

$Q_{\text {in }} \quad$ Heat supplied at evaporator section, W

$\dot{m} \quad$ Mass flow rate of water at cooling block, $\mathrm{kg} / \mathrm{sec}$

$c_{p} \quad$ Specific heat of water, $\mathrm{J} / \mathrm{kg}{ }^{\circ} \mathrm{C}$

$\bar{T} \quad$ Average temperature, ${ }^{\circ} \mathrm{C}$

$Q_{\text {out }} \quad$ Heat rejected at condenser section, W

$R \quad$ Total Thermal resistance, ${ }^{\circ} \mathrm{C} / \mathrm{W}$

lph Liter per hour

\section{Subscripts}

w Water

$e \quad$ Evaporator

c Condenser

V Vapour

$t \quad$ Total 
Journal of Thermal Engineering, Research Article, Vol. 6, No. 5, pp 724-735, October, 2020

\section{REFERENCES}

[1] Faghri A. Heat pipe science and technology. Global Digital Press; 1995.

[2] Park YJ, Kang HK, Kim CJ. Heat transfer characteristics of a two-phase closed thermosyphon to the fill charge ratio. International Journal of Heat and Mass Transfer. 2002 Nov 1;45(23):4655-61. https://doi.org/10.1016/S0017-9310(02)00169-2

[3] Ong KS, Haider-E-Alahi M. Performance of a R-134a-filled thermosyphon. Applied thermal engineering. 2003 Dec 1;23(18):2373-81. https://doi.org/10.1016/S1359-4311(03)00207-2

[4] Noie SH. Heat transfer characteristics of a two-phase closed thermosyphon. Applied Thermal Engineering. 2005 Mar 1;25(4):495-506. https://doi.org/10.1016/j.applthermaleng.2004.06.019

[5] Hussein HM, El-Ghetany HH, Nada SA. Performance of wickless heat pipe flat plate solar collectors having different pipes cross sections geometries and filling ratios. Energy conversion and management. $2006 \mathrm{Jul}$ 1;47(11-12):1539-49. https://doi.org/10.1016/j.enconman.2005.08.009

[6] Guo W, Nutter DW. An experimental study of axial conduction through a thermosyphon pipe wall. Applied thermal engineering. 2009 Dec 1;29(17-18):3536-41. https://doi.org/10.1016/j.applthermaleng.2009.06.008

[7] Jouhara H, Robinson AJ. Experimental investigation of small diameter two-phase closed thermosyphons charged with water, FC-84, FC-77 and FC-3283. Applied thermal engineering. 2010 Feb 1;30(2-3):201-11. https://doi.org/10.1016/j.applthermaleng.2009.08.007

[8] Kannan M, Natarajan E. Thermal performance of a two-phase closed thermosyphon for waste heat recovery system. JApSc. 2010 May;10(5):413-8. https://doi.org/10.3923/jas.2010.413.418

[9] Parametthanuwat T, Rittidech S, Pattiya A. A correlation to predict heat-transfer rates of a two-phase closed thermosyphon (TPCT) using silver nanofluid at normal operating conditions. International Journal of Heat and Mass Transfer. 2010 Oct 1;53(21-22):4960-5. https://doi.org/10.1016/j.ijheatmasstransfer.2010.05.046

[10] Amatachaya P, Srimuang W. Comparative heat transfer characteristics of a flat two-phase closed thermosyphon (FTPCT) and a conventional two-phase closed thermosyphon (CTPCT). International Communications in Heat and Mass Transfer. 2010 Mar 1;37(3):293-8. https://doi.org/10.1016/j.icheatmasstransfer.2009.11.004

[11] Alizadehdakhel A, Rahimi M, Alsairafi AA. CFD modeling of flow and heat transfer in a thermosyphon. International Communications in Heat and Mass Transfer. 2010 Mar 1;37(3):312-8. https://doi.org/10.1016/j.icheatmasstransfer.2009.09.002

[12] Kate A, Kulkarni R. Experimental investigation of elliptical cross section geometry wickless heat pipe charged with distilled water and ethanol. International Review of Mechanical Engineering. 2011 Feb;5(2):369-5.

[13] Ong KS, Tong WL. Inclination and fill ratio effects on water filled two-phase closed thermosyphon. Proceedings 10IHPS, Taiwan. 2011 Nov 6.

[14] Sukchana T, Jaiboonma C. Effect of filling ratios and adiabatic length on thermal efficiency of long heat pipe filled with R-134a. Energy Procedia. 2013 Jan 1;34:298-306. https://doi.org/10.1016/j.egypro.2013.06.758

[15] Solomon AB, Mathew A, Ramachandran K, Pillai BC, Karthikeyan VK. Thermal performance of anodized two phase closed thermosyphon (TPCT). Experimental thermal and fluid science. 2013 Jul 1;48:49-57. https://doi.org/10.1016/j.expthermflusci.2013.02.007

[16] Shabgard H, Xiao B, Faghri A, Gupta R, Weissman W. Thermal characteristics of a closed thermosyphon under various filling conditions. International Journal of Heat and Mass Transfer. 2014 Mar 1;70:91-102. https://doi.org/10.1016/j.ijheatmasstransfer.2013.10.053

[17] Gedik E. Experimental investigation of the thermal performance of a two-phase closed thermosyphon at different operating conditions. Energy and Buildings. 2016 Sep 1;127:1096-107. https://doi.org/10.1016/j.enbuild.2016.06.066

[18] Jafari D, Di Marco P, Filippeschi S, Franco A. An experimental investigation on the evaporation and condensation heat transfer of two-phase closed thermosyphons. Experimental thermal and fluid science. 2017 Nov 1;88:111-23. https://doi.org/10.1016/j.expthermflusci.2017.05.019

[19] Lataoui Z, Jemni A. Experimental investigation of a stainless steel two-phase closed thermosyphon. Applied 
Journal of Thermal Engineering, Research Article, Vol. 6, No. 5, pp 724-735, October, 2020

Thermal Engineering. 2017 Jul 5;121:721-7. https://doi.org/10.1016/j.applthermaleng.2017.04.135

[20] Naresh Y, Balaji C. Experimental investigations of heat transfer from an internally finned two phase closed thermosyphon. Applied Thermal Engineering. 2017 Feb 5;112:1658-66. https://doi.org/10.1016/j.applthermaleng.2016.10.084

[21] Özdemir MR. A review of single-phase and two-phase pressure drop characteristics and flow boiling instabilities in microchannels. Journal of Thermal Engineering. 2018 Oct 1;4(6):2451-63. https://doi.org/10.18186/thermal.465684 